\title{
WOMEN AS DIVINERS AND AS CHRISTIAN CONVERTS IN RURAL SOUTH AFRICA, c. I880-I963*
}

\author{
Sean Redding \\ Amherst College
}

\begin{abstract}
This article argues that rural South African women's importance as spiritual actors in the period from the late nineteenth through the mid-twentieth centuries stemmed from their ability to embrace hybrid spiritual identities that corresponded closely to the lived reality of African rural life, and that by embracing those identities, women expanded their roles as social healers. Professing a belief in Christianity did not prevent individuals from practicing as diviners, nor did it prevent Christians from consulting diviners to determine the causes of death or misfortune. Similarly, young women who converted to Christianity often maintained close ties to non-Christian families and bridged spiritual lives on the mission stations with life in their families. Over this time period, women became cultural mediators who borrowed, adopted, and combined spiritual beliefs to provide more complete answers to problems faced by rural African families in South Africa.
\end{abstract}

\section{Key Words}

South Africa, accommodation to colonialism, women, religion, witchcraft.

In 1943 in the Umbumbulo district in KwaZulu-Natal, South Africa, a case came to trial that concerned issues of supernatural beliefs, divination, witchcraft, and Christianity. A family whose young daughter had died for unknown reasons had previously turned for help to a woman named Annie Cele, who had a reputation as a diviner who could determine the supernatural causes for misfortune. The child's father, Msovu, and her mother, Bakipile, hoped that Annie might provide them with some answers and thereby relieve some of their suffering. The meeting had reached an unexpected conclusion, however. As Msuvo later testified, Annie had mixed Christian prayer with rituals that drew on traditional forms of divination. She 'showed us how she knelt when she prayed', and they all prayed together. Afterward, however, the diviner told them that through her prayers 'she had ascertained that Bakipile had caused the death of the child ... and that Bakipile ... was an mtakati [witch]'. According to Msovu's trial testimony, Annie 'said she got the information that Bakipile was an mtakati from God'.

* I wish to thank the anonymous reviewers and the editors of The Journal of African History for helpful comments and criticisms. I also received incisive comments on an early draft from Robert Edgar and Catherine Higgs. The research for this article was supported by a grant from the Amherst College Faculty Research Award Program, as funded by The H. Axel Schupf 1957 Fund for Intellectual Life.

I KwaZulu-Natal Province Archives Depot, Pietermaritzburg, Records of the Magistrate of Umbumbulo (I/UMB) I/I/I/I, Criminal Case I47/I943, R. $v$. Annie Cele, 26 Feb. I943. 
Annie Cele was on trial in the white magistrate's court on charges of practicing as a witchdoctor, in violation of the Witchcraft Ordinance. The magistrate had to determine if she had indeed accused Bakipile of being a witch, and if she was practicing as a professional diviner; if convicted, Cele would face a jail sentence, a monetary fine, or both. In her trial defense, Cele insisted that she was a Christian and not a 'heathen diviner'. She also denied having indicated that Bakipile was a witch or that Bakipile had killed her child. Another witness testified however, that Annie had indeed made the accusation, although this witness's testimony also supported Annie's protestations of her Christian faith. Annie was 'well known in this district', the witness reported, and 'this power she has of helping people is also well known ... Heathens and Christians come to accused to be prayed for ... Sometimes those cured become Christians.' Other evidence seemed to support Annie's claim of being Christian: She met with clients at the homestead of her friend who lived on a mission reserve and she conducted the ritual, according to the testimony of the witness Willie Makaza, while 'other Christians were singing' hymns. Then she laid hands on the dead child's uncle, who had previously been accused by a different diviner of being the witch who had killed his niece, and she 'could see that his heart was sore'. Annie's accusation, however, laid the blame on the dead girl's mother, Bakipile.

At the trial, Annie's own testimony weakened her defense. In describing how she had gained her supernatural powers she said:

I have never received religious instruction in a school. I do not know how I learnt to pray, but at one time I was sick. I became unconscious on one occasion and while I was still unconscious an invisible person spoke. That person told me that if I wanted to be cured I should place my hands on the sick. I belong to a church and was born a churchwoman. We belong to the American Board Mission. I do not go about bula'ing, smelling out people [accusing people of practicing witchcraft]. I pray for the people who come to me. I believe that they will get assistance from God ... God has given me powers to be able to do this. I often pray for people who are sick. ${ }^{2}$

To those listening in the magistrate's courtroom, this narrative would have seemed reminiscent of the traditional ancestors' call to become a diviner. In addition, other actions that Annie reported suggested a familiarity with the practices of divination. While she denied having lodged any direct accusations against the dead child's mother, she did acknowledge her belief that Bakipile possessed some potentially dangerous 'medicine'. According to Cele's own court statement, 'I said the medicine was very strong and could have affected the child. I asked the woman if she was going to admit or not and she admitted having the medicine' - comments that contained echoes of a diviner's demand that a witch confess to using supernatural medicines. In the end the white magistrate did conclude that Annie was a witch doctor. Annie and her (white) lawyer appealed the verdict, but the conviction was upheld. Her sentence consisted of either paying a substantial fine of $£_{20}$ or serving three months in jail. Annie paid the fine. ${ }^{3}$

Annie Cele's healing ritual combined Christian practices with older methods of divination. This article will argue that Cele was not unique: women's importance as spiritual

2 Ibid. Later in her testimony, Annie Cele denied being a member of the American Board Mission but claimed membership in the Christian Apostolic Church in Zion. 
actors in South Africa in the period from the late nineteenth through the mid-twentieth centuries stemmed from their abilities to embrace hybrid spiritual identities that corresponded closely to the lived reality of African rural life, and that by embracing those identities, women expanded their roles as social healers. As Karen Flint suggests in her study of healing in Natal, illness tended to open people's minds to new therapies, which - whether biomedical or spiritual - became gateways in the encounter between Africans and whites. ${ }^{4}$ Much of the literature on African Christianity, especially as it was practiced in rural areas, stresses the blending of traditional and Christian beliefs, and the way in which the polarized terms of 'Christian' and 'non-Christian' (or 'school' and 'red') may overstate the dissimilarities between the two systems as they were actually practiced. ${ }^{5}$ Professing a belief in Christianity did not prevent an individual from practicing as a diviner, nor, as we shall see below, did it prevent Christians from consulting a diviner. Christian families feared witchcraft just as non-Christians did, and they too called upon diviners to determine the causes of death or misfortune. But while the practices of divination in the twentieth century had clear links to the practices of the early colonial era, there were some clear differences as well. Diviners' powers rested on their claims to spiritual and supernatural authority, and as the example of Annie Cele shows, some elements of Christian worship were often incorporated into divination rituals. At least for some diviners, knowledge of Christian beliefs and rituals gave them additional tools and allowed them to align their practices with the beliefs of those who consulted them. They used these tools to address some of the new problems faced by African families as a result of labor migration, segregation, and deteriorating economic and social conditions in the rural areas of South Africa.

The eastern region of South Africa, comprising both what is now the provinces of the eastern Cape and KwaZulu-Natal, was in the late nineteenth and early twentieth centuries still a contact zone between the culture of white settlers and missionaries and the cultures of several African groups, both Xhosa-speaking and Zulu-speaking. Whites had political control, but many Africans still adhered to precontact religious beliefs even while other Africans converted to Christianity. The process of political takeover and Christian conversion in the nineteenth century created what scholar David Chidester describes as significant constraints on dreams and dreaming among the Zulu; these constraints fostered a larger 'spiritual crisis within the most intimate interiority and personal subjectivity of people living under oppressive colonial conditions' ${ }^{6}$ Chidester notes that dreams and divination were evidence of the fluid phenomena of religious beliefs among the Zulu as they encountered white settlers and missionaries who laid claim both to Zulu land and souls. Dreams were real, not fantasies, and they required real responses; one of the roles that diviners historically played was to interpret the dreams of their clients, and to suggest appropriate

4 K. Flint, Healing Traditions: African Medicine, Cultural Exchange, and Competition in South Africa, I820I948 (Athens, OH, 2008), 93-8.

5 J. Cabrita, Text and Authority in the South African Nazaretha Church (New York, 20I4), 6-I3, I48-59; B. A. Pauw, 'The influence of Christianity', in W. D. Hammond-Tooke (ed.), The Bantu-Speaking Peoples of Southern Africa (2nd edn, London, I974), 436-7.

6 D. Chidester, 'Dreaming in the contact zone: Zulu dreams, visions and religion in nineteenth-century South Africa', Journal of the American Academy of Religion, 76:I (2008), 29. 
responses. ${ }^{7}$ Often ancestors appeared in dreams and asked their descendants for sacrifices and food. As colonial state policies overtook Africans' lives, they increasingly found it difficult to fulfill the demands of their ancestors, and they needed to quiet those demands. Chidester suggests that increasingly in the nineteenth century and later, Zulu people used conversion to Christianity to quiet their dreams. Yet dreams, and the demand to understand them, persisted and sometimes became a site where 'Africans were negotiating new Christian and indigenous religious understandings of a changing world.' ${ }^{8}$

In both Zulu and Xhosa societies, women were often the ones negotiating these new religious understandings, some by acting as diviners, and others by converting to Christianity. The question of women as spiritual actors in South Africa has long been a matter of significant interest in the historical literature. This conversation has included discussions of divination and witch finding as well as of Christianity and conversion. But, much of the literature has suggested that women claimed spiritual roles as a way of overcoming or compensating for their lack of power in the political, social, and economic realms. The anthropologist W.D. Hammond-Tooke, for example, concluded that women frequently became diviners because of the rigid patriarchy inherent in Xhosa and Zulu societies: the genesis of women's emergence as diviners 'was basically caused by female reaction to extreme patriarchy, itself related to a system of patriclans'. ${ }^{9}$ But the idea that women's claims to spiritual power were motivated principally by a desire to heighten their social status tends to flatten the spiritual landscape and see spirituality only as a means to an end. It also assumes that all women were equally low in status in Southern African societies, an assumption challenged by other scholars' findings. ${ }^{\text {IO }}$

A second difficulty with much of the literature on divination is its tendency to paint a static picture of its practices. While Hammond-Tooke, for example, does suggest that Xhosa and Zulu borrowed forms from the San in some remote past, there is little discussion of change or alteration in the more recent past, particularly in response to colonial and missionary influences. Chidester's work provides a possible opening into this world of spiritual alteration and change as precontact beliefs encountered Christian mission teachings. Some women, like Annie Cele, blended the belief in the ancestors with the precepts of Christianity; these women became diviners with Christian tools or Christians with continuing strong ties to 'heathen' family and ancestors. Some women heard a call to divine that they understood as coming from their ancestors; others received the call to convert and understood it to be coming from the Christian divinity. But diviners were not simply

7 A. Berglund, Zulu Thought-Patterns and Symbolism (Bloomington, IN, I989), 97-IO2.

8 Chidester, 'Dreaming', 40.

9 W. D. Hammond-Tooke, 'The uniqueness of Nguni mediumistic divination in Southern Africa', Africa, 72:2 (2002), 285.

Io H. Bradford, 'Women, gender, and colonialism: rethinking the history of the British Cape Colony and its frontier zones, c. I806-1870', The Journal of African History, 37:3 (I996), 360-8; S. Hanretta, 'Women, marginality and the Zulu State: women's institutions and power in the early nineteenth century', The Journal of African History, 39:3 (I998), 4IO-I5; T. McClendon, 'Don't mess with my Ngquthu: articulations of gender and generation in rural South Africa, I928-I948', (http://www.southwestern.edu/ academics/bwp/pdf/200Ibwp-McClendon.pdf), 200I; S. Ndlovu, 'A reassessment of women's power in the Zulu Kingdom', in B. Carton, J. Laband, and J. Sithole (eds.), Zulu Identities: Being Zulu, Past and Present (New York, 2009), I I I-I3. 
re-enacting a precolonial religious role, nor were converts necessarily abandoning their families and cultural identities to become Westernized. As Flint notes in her study of African healing in Natal, women 'may have been the ones who embraced and reinvented the practice of the isangoma [traditional healer] within Natal'. I I Although some Christian converts did experience rejection from their families, and some diviners, like Annie Cele, ended up in court on charges of violating the Witchcraft Ordinance, both converts and practicing diviners often found support in communities that valued them as spiritual actors and as community and family members. Divination by some women and conversion by others became important methods of healing (or attempting to heal) the social rifts and suspicions that emerged in rural African societies as a result of the imposition and entrenchment of colonial rule.

Much of the economic, social, and political life of South Africa was changing rapidly during the period covered by this article. Individual colonial states had overtaken most Southern African societies by I 894, and British rule consolidated control over the region byı902; South Africa became increasingly racially segregated and oppressive of Africans' political and social rights after I9ı0. Rapid industrialization was fueled by gold and diamond mines, and steady streams of African labor migrated between an industrial working life in the major cities and a continuing, but increasingly impoverished, family life based on agriculture in the rural areas. Most women did not join the migratory work force as early as men did, and often remained as farmers and providers for their families in the countryside. But, as the evidence shows, women were not limited to domestic roles, nor were they always confined by precolonial traditions.

The evidence in this article for innovations in women's spiritual roles comes principally from court records and the letters and records of missionaries, and thus has been filtered through layers of white perceptions. And yet portraits of individual women as diviners and Christian converts emerge that show many of the pressures on African lives in the rural areas as well as the ways in which women mobilized spiritual beliefs to respond to those pressures.

\section{WOMEN AS DIVINERS}

Diviners, called 'witch doctors' or 'witch finders' by white colonial authorities, possessed special gifts that allowed them to discern the causes of various types of misfortune: deaths, economic setbacks, seemingly inexplicable illnesses, and occasionally the disappearances of young men who had migrated to work elsewhere and did not return home as expected. Families thus consulted diviners when they were experiencing some particularly vexing or mysterious difficulties. Some difficulties were the same or similar to those faced in precolonial years, but others were new and required new responses or the reworking of old responses to address them fully.

Divination has been the focus of numerous studies over the years of Western engagement with African societies. Missionaries in the nineteenth century typically saw divination as either an expression of demonic possession or as an elaborate charade designed to mislead

II Flint, Healing Traditions, II 7 . 
credulous on-lookers. ${ }^{\mathrm{I} 2}$ These views were of a piece with their general views on African culture: that it was a heathen culture and those who adhered to it (especially when given the option of converting to Christianity) were either evil or foolish. ${ }^{\mathrm{I} 3}$ White magistrates, many of whom were raised in missionary families, often adhered to similar opinions of divination, with the addition of seeing certain types of divination as politically useful to African chiefs who deployed it to undermine enemies or rivals. ${ }^{14}$ Most scholars, writing in the twentieth and twenty-first centuries, have seen divination in a more benign light as a therapeutic practice, even though they usually dismissed its efficacy. The anthropologist Monica Wilson stated, based on her research in the early I930s among the Mpondo in the eastern Cape (specifically the Transkei region), that diviners were not diagnosing illness or misfortune as much as they were social and family tensions:

Amagqira [diviners] are consulted to discover the cause of illness, accident - a fall from a horse, striking of lightning, \& c. - death in man or beast, the wishes of the amathongo [ancestors], the identity of an enemy sending evil omens, and the whereabouts of lost property ... Most often the persons who come to inquire have already decided in their own minds who is responsible for the sickness or trouble, and the igqira [diviner] can judge from the heartiness of their responses whether or not the accusation he $[s i c]$ makes is popular. ${ }^{15}$

This view of diviners' abilities being based partly on a deception and partly on an intuitive reading of their clients' relationships corresponds to anthropologist Michael Taussig's view that diviners engage in a performance that brings secrets to the surface and allows for the voicing of intuitions of harmful thoughts and emotions. Thus, the ritual can resolve social tensions and facilitate a certain kind of healing even if it has no physical effects. ${ }^{\text {I }}$ In contrast, Flint looks at the historical literature for changes in healing strategies among Zulu people, and suggests that the practice of divination was fluid in the late nineteenth and early twentieth centuries with some diviners also practicing as herbalists, and others adopting Western biomedical techniques for remedying physical ailments. Thus, Flint sees divination as one of a number of healing strategies that were alternatives to the strictly biomedical procedures associated with Western doctors but that allowed diviners to borrow some techniques. ${ }^{\mathrm{I} 7}$ Flint's focus on individual healing is complementary to anthropologist Philip Peek's conclusion that divination has often played a broader role in African societies. He writes that divination generally provides 'the context in which old and new, secular and sacred, real and ideal may be contrasted and resolved'. In divination,

I2 See the discussion of Western analyses of African divination in G. Cornelius, 'Chicane: double-thinking and divination among the witch doctors', in P. Curry (ed.), Divination: Perspectives for a New Millennium (Burlington, VT, 2010), I I9-42.

I3 Flint, Healing Traditions, 93-I 27; see also the testimonies by missionaries J. A. Chalmers and B. Ross in Cape of Good Hope, Report of the Government Commission on Native Laws and Customs, I883, Volume II, Part I (Facsimile Reprint, Cape Town, I968), I4I (Chalmers) and 216-I7 (Ross).

I4 Cape of Good Hope, Report of the Native Laws and Customs Commission, I883, Volume II, Part I, 68 (testimony of Sir T. Shepstone).

I5 M. Wilson, Reaction to Conquest: Effects of Contact with Europeans on Pondo (2nd edn, London, I96I), $336-7$.

I6 M. Taussig, 'Viscerality, faith, and skepticism: another theory of magic', in B. Meyer and P. Pels (eds.), Magic and Modernity: Interfaces of Revelation and Concealment (Stanford, CA, 2003), 294-306.

I7 Flint, Healing Traditions, 52-66. 
Peek continues, 'a culture's most cherished values are adapted to the real world of continual flux'. ${ }^{18}$ But in the context explored in this article, it is important to note Chidester's observation that violence became a common feature of Zulus' dreams just as it was a feature of their waking lives under colonial rule: 'Zulu dreams and visions, whether interpreted under traditional or Christian idiom, were undergoing a violent transformation under colonial conditions.' ${ }^{\text {I9 }}$ As we shall see, divination could have violent effects as well. Thus, divination in the eastern Cape and KwaZulu-Natal in this period provided a therapy that responded to the difficulties faced by individual clients as they navigated a world increasingly infiltrated by Western cultural norms.

The authority that people accorded to diviners came from their reputed abilities to contact the ancestors and to inhabit the seen and unseen worlds simultaneously. ${ }^{20}$ People needing the services of a diviner often chose one who had a strong reputation and who lived some distance away; the distance between those who consulted the diviner and the diviner herself lent the diviner's findings additional weight because she could have no 'ordinary' knowledge of the events at issue. ${ }^{2 \mathrm{I}} \mathrm{A}$ respected diviner, as seen in the cases below, could charge substantial fees for her services.

According to the historical evidence, in Xhosa and Zulu societies it was often young women who often felt the call to divine. Women were well-established as diviners in the Transkeian region of the eastern Cape and in KwaZulu-Natal by the mid to late I8oos. Experiencing the call to divine was often traumatic for these women. Twentieth-century narratives from people who became diviners state that they felt compelled by the ancestors to do so and had little choice. The anthropologist Bengt Sundkler noted that among Zulu who became diviners, 'the urge to be possessed by the spirit and to become a diviner is felt as an irresistible force. Few are those who consciously wish to become possessed.'22 The call to divine came in dreams and visions, many of which were frightening, and was accompanied by physical pains. Monica Wilson, in her study of the Mpondo during the I930s, described this call:

Any person who is ill, and whose illness is prolonged, may be diagnosed by an igqira [diviner], or herself feel, that she is 'sick ukuthwasa' that she has an inkathazo (literally trouble), sent by her amathongo (ancestors) who wish her to become an igqira. ${ }^{23}$

Similarly, in 1952 the anthropologist Laura Longmore interviewed a woman from the Transkei about her reasons for training to become a diviner. The woman explained that she had felt a call to divine and that when she tried to ignore it, her ancestors sent her a

I8 P. Peek, 'African divination systems', in P. Peek (ed.), African Divination Systems: Ways of Knowing (Bloomington, IN, I99I), I95.

I9 Chidester, 'Dreaming', 38.

20 H. Callaway, The Religious System of the Amazulu, Part I: Ukulunkulu (Springvale, Natal, I868), 4I7; Wilson, Reaction to Conquest, $38 \mathrm{I}$.

2 I B. Carton, 'Faithful anthropologists: Christianity, ethnography and the making of "Zulu religion" in early colonial natal', in B. Carton, J. Laband, and J. Sithole (eds.), Zulu Identities: Being Zulu, Past and Present (New York, 2009), I60-I.

22 B. G. M. Sundkler, Bantu Prophets in South Africa (2nd edn, London, I96I), 22. See also Berglund, Zulu Thought-Patterns, I36-40.

23 Wilson, Reaction to Conquest, 320. 
variety of ailments: headaches, palpitations, stomachaches, pains around her waist, backache, occasional bouts of hysteria, feelings of 'heavy shoulders', and unsettling dreams:

Lizina often dreams of clear water. There is a green snake that haunts her. She dreams of this. There are times when she sees this snake in broad daylight. She calls others to come and see it. Unfortunately for her, she is the only one who can see it. Although this snake is a snake in almost every way, there are times when it has a human head. Others too who are her relatives often dream of her fishing out a snake from the river. ${ }^{24}$

Eventually, Lizana's mother took her to a diviner, who determined that her ancestors wanted her to become a diviner, and acceding to their wishes was the only way to ease the symptoms. ${ }^{25}$ For people experiencing the call to divine, the accepted way to become a diviner was to seek out an established diviner and begin training with him or her. ${ }^{26}$

Divining was a calling that predated colonial rule. But just as converted Christians in colonial and postcolonial South Africa retained older beliefs and practices, diviners altered their practices as a result of missionary teachings. ${ }^{27}$ With the influx of missionaries in the mid to late I 800 , diviners faced new competitors. Just as magistrates had techniques for fact-finding in court that provided a new kind of response to and diagnosis of evil, missionaries responded to spiritual and physical problems in the seen world by appealing to an unseen realm that previously had been the province of diviners. Some converts were inspired to denounce their pre-conversion activities. In I867, a Wesleyan missionary named Barrett working in the eastern Cape region reported on a conversation he had with a woman who 'informed him that for some time she had been on the point of becoming a Kaffir doctor' (a diviner), and that such practitioners 'get ... their knowledge of the healing art from familiar spirits (in the shape of an animal or other)'. However, she had been diverted from this path by the Christian God: 'She heard the word of God[,] ... became uneasy and came to listen ... She [p]rayed to God to remove ... [her] familiar spirit, and it left her.' In the same moment, she told Barrett, 'Satan left her alone. ${ }^{28}$ Conversely, some diviners - including the famous (male) diviners Ntsikana and Nxele in the early I 800 - used their exposure to Christianity to elaborate their practices. ${ }^{29}$ For their part, missionaries sometimes consciously played on the analogy between themselves and diviners as a way to attract converts. ${ }^{30}$

24 Killie Campbell Library, University of KwaZulu-Natal, KCM 98/8/19/24, Papers of Laura Longmore, 'Appendix: Call to Isangoma', interview with Lizina, originally from Tsolo in the eastern Cape.

25 Ibid.

26 Wilson, Reaction to Conquest, $32 \mathrm{I}-35$.

27 Ibid. 35 I; Berglund, Zulu Thought-Patterns, I38-40; P. Delius, 'Witches and missionaries in nineteenth century Transvaal', Journal of Southern African Studies, 27:3 (2001), 435-40; Flint, Healing Traditions, 8-24; Pauw, 'The influence of Christianity', 436-7.

28 Wesleyan Methodist Mission Archives, Microfiche at Yale University Divinity School, Box 3 I3-I868, No. 746, Letter to General Secretaries of WMMS, 3 Dec. I867, from E. Barrett.

29 J. B. Peires, 'Nxele, Ntsikana and the origins of the Xhosa religious reaction', The Journal of African History, 20: I (I979), 5I-6I.

30 J. Comaroff and J. Comaroff, Of Revelation and Revolution, Volume I: Christianity, Colonialism, and Consciousness in South Africa (Chicago, I99I), 208-I3; A. Porterfield, 'The impact of early new England missionaries on women's roles in Zulu culture', Church History, 66:I (I997), 67-70. 
Like the woman interviewed by Barrett, many of the diviners who were practicing in the region in the mid to late 1800 s were women. In I 896 , the colonial magistrate Charles Brownlee described one episode in which three African policemen, all brothers, came to him for permission to hire a woman 'witch doctor' to discover the cause of one brother's illness. Brownlee refused permission, but the sick brother persisted, reporting that

the 'doctor' he had consulted knew all about his case without having been told. When he appeared before her, she had said to him, 'You served against your own country on the side of the Government [the colonial state] during the last war. You were ill during the war; you were taken to the hospital, and treated there by a white doctor who did not understand your disease. You have thus displeased the spirits of your ancestors by going against their customs and employing those who were endeavoring to bring ruin upon the customs of your forefathers. ${ }^{31}$

The diviner's analysis that physical ailments were the result of moral and political treason ('you served against your own country') provided spiritual reasons for both personal illness and military defeat.

The majority of cases involving diviners that came before magistrates, however, did not involve explicit political critiques. Instead they concerned more intimate tragedies within families. And while cases in the trial records from magistrates in both the Transkei and KwaZulu-Natal show that women often exercised power as diviners of witchcraft, they also show how diviners combined older beliefs with newer practices coming from the colonial context and often used colonially constituted 'Native law' and white lawyers to defend themselves.

The prominence of women diviners continued into the twentieth century and persisted as people moved into towns, as Monica Wilson noted in the r93os among the Xhosa-speaking Mpondo. ${ }^{32}$ Joan Broster, a long-time resident in the Transkei, reported that 'the amagqirha [diviners] maintain that ukuthwasa [the call to divine] always runs in families and the spirit usually returns to this world through a daughter or a granddaughter', suggesting that women were portrayed as possessing a special capacity for this type of spirituality. ${ }^{33}$ Indeed, as the meaning and practice of divining was changing in response to new influences, women became more profoundly identified with spiritual power. ${ }^{34}$ There is evidence that among Zulu-speakers the number of women who became diviners increased in the late nineteenth and early twentieth centuries, possibly as a result of various social and spiritual disruptions. ${ }^{35}$ Berglund notes that his informants felt that although women diviners used to be called by the ancestors of their own lineages, in the twentieth century, they were often called by their husbands' ancestors. Berglund cites an informant who told him that because men were away at work so much, 'the shades [ancestors] of the homestead are troubled, finding only the wife at home. So they trouble her, seeing that the

3 I C. Brownlee, Reminiscences of Kaffir Life and History (Lovedale, I896), 248-9.

32 Wilson, Reaction to Conquest, 320-I, 487-502.

33 J. A. Broster, Amagqirha: Religion, Magic and Medicine in Transkei (Goodwood, I98I), 22.

34 Comaroff and Comaroff, Revelation and Revolution, Volume I, I 56-9.

35 Flint, Healing Traditions, I I6; J. Parle, 'Witchcraft or madness? The Amandiki of Zululand, I894-I9I4', Journal of Southern African Studies, 29:I (2003), I07-I6; S. G. Lee, 'Spirit possession among the Zulu', in J. Beattie and J. Middleton (eds.), Spirit Mediumship and Society in Africa (New York, I969), I3I; Sundkler, Bantu Prophets, 23; P. Harries, Work, Culture, and Identity (Portsmouth, I994), I63-6. 
husband is away. ${ }^{36}$ Given the disruption of African societies in both the eastern Cape and KwaZulu-Natal caused by the imposition of white rule in the region, it is not surprising that people looked to the answers provided by diviners not only to diagnose illnesses but also to find a cause for political and social disruptions. But the diviners themselves became targets of colonial laws that made divination and witchcraft accusations illegal.

For example, a I908 court case concerned a female diviner from the Qumbu district of the Transkei who had been brought to a homestead to discern the cause of the illness of the father in a family. The diviner was on trial for being 'by habit and repute' a 'witch doctor', a crime under the Witchcraft Ordinance. According to a witness at the trial, the diviner had conducted a ritual and indicated that the man's two wives were trying to kill him through the use of magical medicines. As a result, the wives left the district, probably to avoid the consequences of being named as witches. Even though at the trial the diviner denied having named the women as witches, the magistrate found her guilty of being a witch doctor, and sentenced her to six months of imprisonment with hard labor or payment of a $£_{\mathrm{I}} 5$ fine. ${ }^{37}$ In convicting the diviner the magistrate was effectively condemning both the belief in witchcraft and in divination and the community that held it.

Another case from the Bizana district of the Transkei in I909 made this inherent conflict between magistrates and diviners clear. A man named Silimela had become ill, and three of his male relatives had consulted a woman diviner. Two of these men were on trial for subsequently threatening an accused witch with arson, while the third relative had agreed to testify for the prosecution. He stated that the diviner, named Mantunya, had accused his wife of causing Silimela's sickness, by sending 'her Tikolotshi [a malevolent supernatural being] to put medicine in Silimela's mouth during the night'. After the consultation they had returned home, but two days later the two other men had arrived at his home and 'said they had come to burn my hut because my wife Maluma had caused the death of Silimela, Silimela having died that day. My wife's life is endangered through this because I presume they meant to burn her in the hut.' ${ }^{8} 8$ These two men were convicted by the magistrate of threatening arson and were required to pay a fine of $£_{\mathrm{I}}$ each or to serve one week in jail with hard labor. At the subsequent criminal trial of the diviner, she admitted that she was a 'witch finder' and that she had been consulted by the three men, but she denied having indicated that Maluma was a witch. The magistrate did not believe her denial, convicted her under the Witchcraft Ordinance, and sentenced her to one year of jail with hard labor with no option of paying a fine. The disparity between the relatively light punishments meted out to the two men who had actively threatened to burn down the huts of the suspected witch as opposed to the more significant punishment accorded to the diviner is a striking indication of how dangerous the magistrate believed her power to be.

But the diviner in this case showed both her cultural adaptability and her access to material resources. She hired a local (white) lawyer to defend her and appealed the verdict.

36 Berglund, Zulu Thought-Patterns, I39.

37 Cape Province Archives Depot, Cape Town, Records of the Resident Magistrate of the Ngqeleni district, Transkei (I/NQL) I/I/I/8, Case 28 of I908, R. $v$. Zumani alias Nomtobwana, 28 Jan. I908.

38 Cape Province Archives Depot, Cape Town, Records of the Resident Magistrate, Bizana district, Transkei (г/BIZ) I/I/9, Criminal Case Ioo/ı909, R. v. Mayingwa and Nxayipi, 30 Apr. I909. 
The magistrate, in providing his reasons for the original conviction and sentence, emphasized the malign influence of diviners and the need to make an example of Mantunya:

The extraordinary fear with which witchdoctors are regarded by natives is an important factor in this case, it is so great that it is almost impossible to get any native, even the so-called educated ones, to give evidence against them, and in this case, it was only the fact of his own wife having been indicated, that caused Nozukwa to give the evidence [against the diviner that] he did. ${ }^{39}$

Both the verdict and the sentence were upheld on appeal by the Chief Magistrate of the Transkei. But the diviner's hiring of a white lawyer to appeal the conviction suggests two further points: that divining was a lucrative enough profession to allow Mantunya to employ a lawyer, and that she was willing to make the necessary adaptations in order to survive the cultural and legal challenges that colonial authorities presented.

Indeed, the power of diviners persisted despite the efforts of the state to punish them. Magistrates typically regarded diviners as dangerous charlatans who needed to be punished publicly. Part of that position likely stemmed from their empathizing with innocent people condemned as witches. But part of it derived from their recognition that diviners, although rarely explicitly political in their statements, often competed for authority with the state. ${ }^{40}$ In justifying the four-month imprisonment he had imposed on a female diviner in a 1943 case, a magistrate in KwaZulu-Natal stated that the sentence was necessary 'because of the gravity of the crime committed and the seriousness of the consequences of these ... smelling out ceremonies'. He noted the sharp increase in the number of cases that he had seen, the power wielded by the diviners in their communities, and the impunity with which they operated.

In the past few months ... the life of many families has been disrupted because a member has been [indicated] as an Mtakati [witch] by an isangoma [diviner]. Huts have been burned down and in one instance, now the subject of a preparatory examination into a murder, there is evidence to the effect that the death of a Native was caused by a person who had been accused by the deceased as having been smelt out as a mtakati by an isangoma. Evidence against these witchdoctors is for obvious reasons hard to procure and so great is the belief of the people in their pretended power that they go about in dread of their evil influence. ${ }^{4 \mathrm{I}}$

In these circumstances, he insisted, harsh sentences were needed to break the power of the diviners.

By I948, as South Africa's race-based policies became more stringently defined under the system of apartheid, the judicial sentences against diviners became even harsher in the Cape Province, the Transkeian territories (which were administered as a separate region of the Cape), and KwaZulu-Natal. In the Transkeian territories, anyone who was convicted in a court of being a witch doctor could be fined (with the amount left to the discretion of the court), sentenced for up to five years with hard labor in jail, or punished with I 5 lashes, or the person could receive any two of these penalties. In the rest of the Cape Province a convicted 'habitual witch doctor' faced a fine of $£_{5} \circ$, a term of imprisonment

39 I/BIZ I/I/9, Criminal Case I0I/I909, R. v. Mantunya, 30 Apr. I909.

40 Flint, Healing Traditions, I04-9.

4 I I/UMB I/I/I/I, Criminal Case I/43, R. $v$. Nokwenzini Miyeza, I 5 Jan. I943. 
of up to two years, 36 lashes, or any two of these penalties. In Natal and Zululand, any person convicted of 'falsely accusing' a person of witchcraft could be punished by a fine, imprisonment, 25 lashes, or any two of these. The Union of South Africa's Secretary of Native Affairs, in writing about these punishments to the Secretary of Justice in I948, remarked on the prevalence of such cases and the problems of prosecuting them, particularly because it was 'extremely difficult for the Crown to prove that a person is a witch doctor by habit and repute'. He elaborated that many magistrates and native commissioners 'express the view that the witchdoctor should, at the discretion of the Court, be subject to the same penalties as the murderer, in cases where there has been a killing'. ${ }^{42}$ In some cases, as we saw in the I909 case of Mantiniya discussed above, convicted diviners already received harsher sentences than people who committed the physical crimes following the witchcraft accusation.

Despite these penalties, the influence of diviners persisted, as shown by an unsettling case from Ngqeleni district in the Transkei in I952. Early in the year a father with a sick child traveled to a diviner along with three women: two were wives of his elder brother and one was his sister. He suspected that there was a supernatural cause behind his child's illness, and the visit to the diviner led him to murder one of his sisters-in-law. This tragic outcome resulted in two trials - his own for the actual murder and the diviner's for making the accusation of witchcraft that had led to the murder. As the father later testified at the trial of the diviner,

Accused [the diviner] said the child had been killed by Maxahishe [one of his brother's wives who accompanied him] and pointed her out. Accused did not mention Maxahishe's name; she just pointed her out. Accused said a snake from her had gone into the child's head and that the snake had been sent by its owner.

At the divination ceremony, Maxahishe had asked the diviner where she might have gotten the snake, and the accused said 'From your mother's people.' The man paid the diviner $£_{\mathrm{I}-\mathrm{IO}}$ shillings and he and his kinswomen left on their return journey. 'On the same day', the man testified, he killed Maxahishe as they walked home. He was testifying against the diviner, he reported, after he had himself 'been convicted of the murder of Maxahishe and sentenced to ten years imprisonment'. He explained his motive for the murder:

I was angry because Maxahishe had caused the illness of my child. I killed her on the way home. I would not have killed her if accused had not smelt her out as the cause of the illness of my child. I suspected Maxahishe of causing the illness of the child even before I consulted the accused. Maxahishe had already been smelt out by other witchdoctors.

At the trial, the woman accused of being a diviner, Maxalanga Centani, denied the charge and insisted that she was only an herbalist. She admitted to having been consulted by the man and the three women about the child's illness, but she claimed that she had told the father to take the child to a white doctor. Unfortunately for her, however, the two surviving women corroborated the father's version of events, and one added in her testimony that the murdered woman was 'well known as a witch', and she had not been surprised by the

42 Union Archives, Pretoria Archives Depot, Records of the Native Affairs Department (NTS) 9564, File 5/394, Letter dated 1948, Secretary of Native Affairs to the Secretary of Justice. 
diviner's accusation. The magistrate convicted Centani of being a diviner, and sentenced her to a year in jail with hard labor. ${ }^{43}$

As in the cases described above, it was often women, particularly wives and widows, who were accused by diviners of witchcraft. Such accusations mirrored their often tenuous positions in rural homesteads. The father in the above case suspected his sister-in-law of being a witch, a suspicion confirmed by the diviner. Family tensions became more socially destructive because of increasing labor migration from the rural areas in the 1950 os and I960s and the policies of influx control that crowded families in rural reserves like the Transkei and parts of KwaZulu-Natal. Illnesses and deaths, particularly of children, might easily have been interpreted as resulting from family jealousies or arguments between neighbors. Other accusations against women could emerge from increasing pressures on land tenure. The state typically allocated plots of communal land to male heads of households, but usually if a man died his widow had the right to continue to farm the land as long as she lived there and paid the required taxes. This situation created a dangerous condition for some widows as farmland became increasingly scarce in the reserves, and their continued occupation elicited resentment within the family. ${ }^{44}$ In a I95 I arson case involving a man who had been convicted of destroying the hut of his sister-in-law, a supposed witch, the appeals court that reviewed the verdict and sentencing stated that 'the case is a very simple one. There are circumstances connected with it, which to anyone knowing anything about the Transkei must carry weight. As is usual an old widow was picked on and her hut was burned.' ${ }^{45}$ A second source of danger for a widow, especially a widow of a man who had died when he was relatively young, was suspicion from his family - often with the confirmation of a diviner - that she bore some responsibility for the death. ${ }^{46}$

Women were not the only ones suspected of using witchcraft. Along with tensions within rural families, the I950s and I960s saw a surge in violence directed against the apartheid state. As Africans confronted new agricultural and political policies that threatened their livelihood, resentment against the implementation of the apartheid-inspired 'homelands' policies turned an already simmering political situation into a broader revolt that challenged the state's control on every level. One of the key elements of the revolt was the suspicion that agents of the state, including collaborating chiefs and headmen, were using witchcraft against ordinary people - an idea reinforced by the state's ongoing campaign against diviners. ${ }^{47}$ There is some evidence to suggest that a few diviners actively engaged in the rebellion, for example, by providing herbal 'medicines' to protect rebels. The small group of Poqo activists who in I 962 tried to assassinate noted apartheid collaborator

43 I/NQL I/I/I/I4, Case 645, R. $v$. Matshezi alias Maxalanga Centani, Io Nov. I952.

44 S. Redding, Sorcery and Sovereignty: Taxation, Power and Rebellion in South Africa, I880-1963 (Athens, $\mathrm{OH}, 2006)$, I72-3; Berglund, Zulu Thought-Patterns, 260.

45 The man had been sentenced to three months in jail with hard labor, and the appeals court suggested that if anything the verdict was too lenient (Cape Province Archives, Cape Town Archives Depot, Records of the Resident Magistrate of Flagstaff district, Transkei (I/FSF) I/I/I/32, Case 262 of $195 \mathrm{I}, \mathrm{R} . v$. Miswa Mhlekwa, 4 June I951).

46 P. Mayer, Townsmen or Tribesman? (2nd edn, Cape Town, I961), 242.

47 Redding, Sorcery and Sovereignty, $175-200$. 
Chief K. D. Matanzima at his Great Place in the Transkei had all, according to one participant, gone through 'initiation services and washing ... with doctored water which would immunise [them from] European bullets'. ${ }^{48}$ This ritual had been performed by a man in Cape Town, although the rebels also apparently knew of a female diviner who could perform this kind of 'war-doctoring' in Mthatha (Umtata) district. ${ }^{49}$

While not all divination and supernatural practices were explicitly political, what does seem clear is that diviners offered innovative responses to the social, political, and legal challenges posed by colonial control. Many women in particular became known within their communities as having access to spiritual powers, which they could use to diagnose the causes of these challenges and to provide a way to resolve them as well. Many of these powers came from their traditional source among the ancestors, but some also had their source in Christian beliefs.

\section{CHRISTIAN CONVERTS AS DIVINERS}

From the mid-nineteenth century onward, missionaries and mission stations were common throughout the eastern Cape-Transkei region and KwaZulu-Natal. Gradually, Christian cultural influences seeped into African life, even among families who did not convert. Although white missionaries rarely condoned any combining of non-Christian beliefs with mainstream Christianity, Christian Africans did usually retain at least some elements of their pre-existing cultures. Indeed, this heterogeneity of belief, well-documented for the eastern Cape and parts of Natal, often eased social tensions between Christians and non-Christians. In both the eastern Cape and in KwaZulu-Natal, individuals sometimes converted without renouncing their beliefs in the ancestors and in the possibilities of witchcraft. The combination of Christianity with divination was a powerful harnessing of the diagnostic and healing powers of the ancestors with those of the Christian God, as both Chidester and Flint have suggested. The combination of old and new practices may have seemed to combine the potential to heal some of the new physical and social ailments faced by African individuals and communities. ${ }^{50}$

Conversion to Christianity did not prevent some women from practicing as diviners, as we have already seen with the case of Annie Cele, nor did it necessarily protect some women from being named as witches. In a case from 1928 in the Nqamakwe district of Transkei, a widow, named Maria, from a Christian family was identified as a witch by a female diviner who was consulted with the encouragement of the dead husband's brother. Maria, who described herself as 'a full member of the Wesleyan Methodist Church', went to the police after she was named as the witch who had caused her

48 Cape Province Archives, Cape Town Archives Depot, Records of the Chief Magistrate of the Transkeian Territories (CMT) 3/I48I, File 42/20, Letter from the Bantu Affairs Commissioner of Cofimvaba district to the Chief Bantu Affairs Commissioner, I3 Dec. I962. See also, CMT 3/I48 I, File 42/20, Statement of A. Mabusela, typescript, I6 Dec. I962, 3 pages, signed by A. Mabusela (statement given in Xhosa and translated by W. Kota in the magistrate's office).

$49 \mathrm{CMT}_{3} / \mathrm{I}_{4} 8 \mathrm{I}$, File 42/20, various statements from Poqo members arrested by police, attached to letter by Security Branch police in Cofimvaba, Statement by Howard Lewu, Oct. I96I.

50 Chidester, 'Dreaming in the contact zone', $38-43$; Flint, Healing Traditions, I I2-I8. 
husband's death; this resulted in the later trial of the diviner for violating the Witchcraft Ordinance. Maria testified that the family had discussed consulting a diviner, and that her brother-in-law told her that 'he was prepared to go to hell' in order to find out who had caused his brother's death. His suspicion had focused on her because her children had all died at young ages, and because she had been 'smelt out' as a witch on a previous occasion. There may also have been some material motivation behind the suspicion. At the diviner's trial the widow testified that her husband had owned quite a bit of property and that the brother would 'inherit the property if I die or leave my husband's kraal [homestead] without the approval of his relatives'. According to the trial testimony, the diviner had arrived for the consultation 'dressed in school-Kaffir costume' (the clothes typically worn by a Christian African woman) but then she had 'changed into a head-dress and armlets' (dress befitting a diviner). She had danced as part of the ritual of contacting the ancestors, and then accused Maria of possessing an mpundulu (a magical lightning bird) that Maria had allegedly directed to murder her husband. The diviner also said that 'three little balls had been removed from above the door' of the family home, and these were supposedly supernatural medicines concocted from the blood and hair of dead people who had been exhumed. Maria, who testified that she was 'terrified by all this', denied that she was a witch but offered to leave the household, even though by doing so she would have forfeited her right to farm her deceased husband's land. Upset by the witchcraft accusation and obviously aware of the illegality of divination, Maria later complained to her headman, and her complaints led to the trial in the magistrate's court. At the trial, the diviner denied that she was a 'witch doctor', and stated that she had only gone to the homestead to treat the brother-in-law for bodily aches with herbal medicines. A number of witnesses corroborated the widow's testimony, however, and the diviner was convicted by the magistrate and sentenced to pay a $£_{\mathrm{I}} 5$ fine or to serve six months in jail. ${ }^{5}$

In this case, the family members apparently did not feel that their concerns and suspicions could be addressed adequately by their church, and decided to employ a different type of spiritual specialist, one who bridged the divide between Christianity and the ancestors. Although the diviner in the case dressed in Western-style clothing, it is unclear whether she herself was a Christian, but she was clearly willing to divine for a family that professed Christianity. Like Annie Cele, who blended Christian prayer and non-Christian divination, she was conversant in both worlds. These hybrid spiritual identities and practices went beyond a simple borrowing of rituals or clothing. They instead show how Africans, whether Christian or not, adapted to a changing world while still adhering to an inherited spiritual worldview and turning, in times of crisis, to time-tested explanations for calamities. Women who practiced divination reflected the worldviews of the communities in which they operated, and they combined beliefs and rituals that served their spiritually heterogeneous society. The violence that sometimes followed a witchcraft accusation, whether that involved expelling the named witch from the family, burning her huts, or in some cases killing her, perhaps reflected the often draconian punishments meted out to diviners by magistrates and the more structural violence imposed by

5 I Cape Province Archives, Cape Town Archives Depot, Records of the Magistrate of Nqamakwe district, Transkei (I/NKE) I/I/I/40, Case I03 of I928, R. $v$. Putunywa Madinga, 25 July I928. 
colonial rule generally. As we shall see in the next section, the relations between non-Christian families and individual family members who chose to convert also sometimes erupted in violence as families tried to prevent their children from converting. But other families were able to embrace the converts and even use Christianity to mitigate some of the challenges posed by white rule.

\section{YOUNG WOMEN'S CONVERSION TO CHRISTIANITY AND THE DEVELOPMENT OF HYBRID SPIRITUAL IDENTITIES}

Many scholars have analyzed women's conversion to Christianity in nineteenth- and twentieth-century South Africa as evidence of generational conflicts, particularly conflicts over marriage and sexuality. The move to the mission station is often framed as an attempt to escape the patriarchal control of African society. ${ }^{52}$ Women who converted to Christianity sometimes left their families to join Christian communities, and in these cases conversion - especially on the part of women who left their families as marriage negotiations were underway - was often regarded as a dangerous act that threatened the families' continuation into the future. Meghan Healy-Clancy, in her study of girls running away to the Inanda mission in KwaZulu-Natal, affirms that many of the girls were fleeing intergenerational tensions in general and unwanted marriages in particular. ${ }^{53}$ Among the older generations, African parents or elders who rejected Christianity generally saw themselves as keepers of the connection with the ancestors and the old culture, and they saw children who defied them and rejected their beliefs as contributing to the demise of an entire way of life. As Monica Wilson noted in her studies of Mpondo communities in the I930s, the divisions that resulted between the converted and the nonconverted were deep enough to emerge even in casual conversation:

If when the dogs bark as someone goes past and a child is asked by its parents, who passes, a Christian child will say, if it be a Christian who has passed: 'Ngumntu' (It is a person); if a pagan: 'Liqaba' (It is one who grinds ochre - the usual word for a pagan). A pagan child when a Christian passes will say: 'Liqoboka' (It is 'one who has turned round' - the usual term for a Christian); of a pagan: 'Ngumntu'. ${ }^{54}$

Despite evidence of family tensions, however, whether such conflicts preceded and caused the conversion or whether they resulted from the conversion may have varied among individual cases. ${ }^{55}$

Aside from possible familial and community-wide discord, women who converted were part of a broader cultural contestation between colonial society and African

52 Wilson, Reaction to Conquest, 353; B. Carton, Blood from Your Children: The Colonial Origins of Generational Conflict in South Africa (Charlottesville, VA, 2000), 72-5.

53 M. Healy, "To control their destiny": the politics of home and the feminisation of schooling in colonial Natal', Journal of Southern African Studies, 37:2 (20I I), 252-3.

54 Wilson, Reaction to Conquest, $35 \mathrm{I}$.

55 Killie Campbell Library, University of KwaZulu-Natal, Records of the Inanda Seminary, KCM 52IO2, Box Ia, 'Some facts bearing on the condition of Kraal girls', dated Groutville, I I May I893, by H.D. Goodenough. 
communities. ${ }^{56}$ Just as white female missionaries and missionaries' wives were expected to model proper Christian behavior for African women and families, African women in particular were often targeted by missionaries for conversion. The Reverend Elijah Makiwane, speaking on the topic of Christian education to the Native Education Association in I885, noted the need for increased conversion and education among African women as a way of ensuring that Christian converts would raise a new generation of Christians:

I lay great stress on the reality and importance of the influence of what are called better halves, and our thanks are specially due to those who are training native girls ... No nation can advance except through the improvement of the nation's homes; and they can only be improved through the instrumentality of women. ${ }^{57}$

Typically, missionaries saw girls who arrived at mission stations as seekers of the truth; and if girls arrived who were fleeing their parents or unwanted marriages, missionaries saw them as martyrs to the faith and in need of refuge. Particularly in the late nineteenth and early twentieth centuries, missionaries tended to equate polygyny with immorality and parentally-arranged marriages and the payment of bridewealth (or lobola) with forms of labor bondage. A long-time missionary in the Cape, the Reverend John Longden, stated in 1883 that he saw bridewealth as a payment made by the husband's family for the loan of the woman as a laborer: 'A father agrees to lend his daughter to a man on condition that a stipulated amount ... be paid for the loan, in consideration of the children she shall bear him, and the service she shall render him.' Longden concluded that a woman 'can hardly be said to have any social status. She is not regarded as the equal of her husband and her condition is servile. ${ }^{58}$ And the magistrate of Empangeni in KwaZulu-Natal, A. R. R. Turnbull, commented to the I902-3 Native Affairs Commission that in Zulu society, 'The men work merely to obtain money wherewith to pay their hut and other petty taxes, and to purchase cattle to pay as "lobolo" for girls, their so-called wives, or slaves to work for them. ${ }^{59}$ While these views of the subordinated role of African women may have misrepresented their actual status, these views were widely held by whites, who thus often saw Christian conversion and marriage into Christian households as providing a form of rescue for African women.

Certainly there is much to question in this discourse, including the motives of those who voiced it. Many scholars have demonstrated that Christian colonial society was as patriarchal as precolonial African societies had been. Ben Carton, in discussing the phenomenon of girls and young women leaving their homesteads in KwaZulu-Natal to live on mission stations, suggests that the move amounted to exchanging one form of patriarchy

56 N. Etherington, 'Gender issues in South-East African missions, I 835-85', in H. Bredekamp and R. Ross (eds.), Missions and Christianity in South African History (Johannesburg, I995), I47-9.

57 Lecture given by the Rev. Elijah Makiwane on the subject of 'Native Education' to the members of the Native Educational Association, reprinted in Imvo Zabantsundu (Native Opinion), 9 Feb. I 885, 3-4. I am indebted to Dr Harrison M. Wright for giving me access to his microfilm collection of Imvo.

58 Cape of Good Hope, Commission on Native Laws and Customs, I883, Volume II, Part II, Appendix C, 9I.

59 Union Archives, Pretoria Archives Depot, Records of the I902-I903 Native Economics Commission, C I7, Vol. 6, Written Replies by A.R.R. Turnbull, Lower Umfolozi Division, Zululand, 8 Dec. I903. Both Dinnerstein and Houle analyze these views held by missionaries: M. Dinnerstein, 'The American Zulu Mission in the nineteenth century: clash over customs', Church History, 45:2 (I976), 235, and R. J. Houle, 'Mbiya Kuzwayo's Christianity: revival, reformation and the surprising viability of mainline churches in South Africa', Journal of Religion in Africa, $38: 2$ (2008), I48. 
for another. ${ }^{60}$ Missionaries also had practical motives in encouraging the conversion of women since they recognized the potential difficulty of retaining male converts if there were few Christian women for them to marry, and they recognized that the presence of marriageable women at the mission stations would increase their appeal. ${ }^{6 \mathrm{I}}$ In addition missionaries (and magistrates) saw the conversion of young people as a way to construct a more profound control over the African population both at large and over the long term.

Missionaries, to be sure, intentionally reordered the lives of Africans living on mission stations to reflect Christian beliefs. ${ }^{62}$ In mission schools, religion and Bible readings were woven throughout the curriculum, and school days typically opened with prayers and hymn-singing. In the case of boarding students, the school day often extended into the evening with sessions on religious subjects. Students were steeped in Christian thought and sentiment, and conversion was the intended outcome.

African communities were aware that, in addition to conversion, education was also a firm part of the Christian mission. Non-Christian parents often willingly sent children to mission schools, in all likelihood motivated by practical and educational goals that outweighed any possible hesitations on religious grounds. Mission schools taught the useful skills of literacy and numeracy; from a family's point of view, a literate child could function as the family members' personal translator in their dealings with the white-controlled government as well as providing some protection from being cheated by the local trading station or by white employers. And while a child's education in mission schools often had an impact beyond what some parents may have hoped for, it did not necessarily result in conversion or undermine a family's belief in its own religion. As Patrick Harries has noted, 'literacy often served to reinforce local beliefs rather than challenge or transform them'. ${ }^{63}$ Schooling thus had advantages that for some families outweighed the risk of losing spiritual or even physical control over a child. ${ }^{64}$

At the same time, among families and communities who resisted conversion, and even among converts themselves, their positions or points of view were not necessarily consistent or absolute. For young women as well as young men, conversion, as in the cases of the diviners discussed above, was frequently not an either-or process. Baptized or not, many Africans adhered to blended traditions that spliced together various strands of religious truth, and families could harbor both Christian converts and firm believers in the old religion. ${ }^{65}$ African converts themselves were often aware that there was a difference between

60 Carton, Blood from Your Children, 72-5.

6I Etherington, 'Gender issues', I47-9; J. Hodgson, 'A battle for sacred power: Christian beginnings among the Xhosa', in R. Elphick and R. Davenport (eds.), Christianity in South Africa: A Political, Social and Cultural History (Berkeley, I997), 80.

62 I. Hovland, 'Umpumulo, place of rest: a nineteenth-century Christian mission station among the Zulus', Radical History Review, 99 (2007), I45-6.

63 P. Harries, 'Missionaries, Marxists and magic: power and the politics of literacy in South-East Africa', Journal of Southern African Studies, 27:3 (2001), I I 7.

64 N. Etherington, 'Kingdoms of this world and the next: Christian beginnings among Zulu and Swazi', in R. Elphick and R. Davenport (eds.), Christianity in South Africa: A Political, Social and Cultural History (Berkeley, I997), 98-100.

65 R. J. Houle, 'Becoming Amakholwa: Revival and the Formation of Group Identity on the Stations of the American Zulu Mission, I890-I910', conference presentation, African Studies Seminar (University of KwaZulu-Natal, Durban, 2003), 2-5; W. G. Mills, 'Missionaries, Xhosa Clergy and the suppression of 
becoming Christian and becoming completely 'Westernized' ${ }^{66}$ In the most general sense, just as women diviners served as a mediating presence between African communities and the effects of white rule, working for the well-being of the former while also helping to explain, control, and remedy the worst effects of industrialization and other cultural changes imposed by the latter, mission-educated youth and even Christian converts occupied an intermediary terrain that may have helped to ease the conflicts experienced by their families, even if their presence sometimes created other tensions. ${ }^{67}$

There is room for an analysis that confirms the missionaries' point of view that a parentally arranged marriage, particularly to an older non-Christian man, could have represented a genuine crisis for an adolescent girl who had attended a mission school - or at least that young women who fled to the missions were demonstrating and enacting personal agency. ${ }^{68}$ It is also worth considering that for some girls and young women, the desire to convert, beyond the influence exerted by the missionary presence, was sincere and perhaps similar to the call to divine felt by other young women. In their discussion of the conversion experience of the twentieth-century religious leader Nontetha Nkwenkwe, Robert Edgar and Hilary Sapire point out that the young girl's call to convert in many ways resembled the spiritual call of the ancestors (ukuthwasa) with an ecstatic and immediate moment of revelation and clarity. ${ }^{69}$ The spiritual concerns and beliefs that these young women held might have been incorporated into personal identities that led them to look for religious guidance at a mission station, just as those called to divine might seek training with an established diviner.

A series of missionaries' letters describing the girls and young women who came to the mission stations of the American Board Mission in KwaZulu-Natal in the I88os and I89os suggest that many girls who arrived at the stations were indeed fleeing undesired marriages: 'the unwritten history of native marriage alliances contains much tragic violence', wrote one missionary. ${ }^{70}$ But another common thread in the narratives is the sincere desire of many of these young women to be Christian. And even though the narratives were written by white missionaries, one finds enough individual variation in the stories, particularly involving the motivations of the girls and their differing circumstances, to make them plausible. Not all converts were trying to escape arranged marriages; in many cases they seemed

traditional customs', in H. Bredekamp and R. Ross (eds.), Missions and Christianity in South African History (Johannesburg, I995), I66-7.

66 Dinnerstein, 'The American Zulu Mission', 244.

67 Delius, 'Witches and missionaries', 436-40.

68 Meghan Healy-Clancy notes that from relatively early in the American Zulu Mission's existence, missionaries often encouraged girls to run away to the mission stations, and this encouragement became a source of tension between the missions and the local populations (Healy, 'To control their destiny', 249-50).

69 Edgar and Sapire make this last point in their discussion of Nontetha Nkwenkwe's conversion to Christianity: 'The account of how she was called to prophecy bears a similarity to the classic trajectory of becoming a diviner. In some respects, her illness resembles ukuthwasa .... R. Edgar and H. Sapire, African Apocalypse: The Story of Nontetha Nkwenkwe, a Twentieth-Century South African Prophet (Athens, OH, 2000), IO.

70 KCM 52 I05A, Inanda Seminary Papers Box Ia, 'To the Honourable Legislative Council of Natal, a Petition Relating to the Protection of Native Girls Wishing to Renounce Heathenism for Civilization and Christianity', I893. 
to be seeking either a community with beliefs similar to their own or the answers to spiritual questions, or both.

The records of the Amanzimtoti mission in Zululand describe the case of an enterprising thirteen-year-old-girl named Nomame who ran away to the mission station, bringing with her fabric for a new dress purchased with money she had earned. This detail about the dress material was not merely incidental; Western-style clothes were the most visible symbol of a girl's adoption of Christianity and often of her defiance of non-Christian parents. ${ }^{7 \mathrm{I}}$ Girls who ran away from home to the mission often brought fabric to make their own clothes, and parents trying to reclaim their daughters often confiscated and destroyed the clothes the girls had worn while at school. In this case, when the girl's mother arrived to take her back, she complained that Nomame's flight had been instigated by her uncle, who was a Christian preacher. The missionaries refused to surrender Nomame, and the next day her brother came for her: 'He was exceedingly angry', one of the missionaries reported, 'and had been the night before to Umbovu (the preacher) accusing him of helping the girl run away, thrusting at him with an assegai, and saying "Your blood for this." Frightened by this threat, the missionaries agreed that the uncle should return the girl to her parents, 'though she had to be wrenched away from the veranda post to which she clung'. Back at home, she worked out a compromise with her family. She 'receiv[ed] a promise from the mother and brother that they would not beat her, and that she would be allowed to dress [in Western clothing], attend the station school and chapel.' Nevertheless, she did not appear at school or chapel the next day. Then, the following afternoon she came running into the prayer-meeting in the chapel, closely followed by her mother.

The clothes she wore when she left us had been taken from her. She clung to Mr. Ransom [another missionary] and me, and we brought her home with us. Her mother hung about till after nightfall and has been once since to ask that the girl might return [home]. Nomame had been beaten the day she stayed at home, and ... [there was] a cut on her body and welts occasioned by the whipping on her limbs. ${ }^{72}$

The anger that her family felt at her spiritual defiance was evident in these marks.

Not all conversions, however, created such a traumatic break between a daughter and her family. In one case, marked as Case No. I in the Inanda Mission archives, a girl named Sanaye showed a great deal of personal initiative in coming to the mission station. She had arrived in the late $\mathrm{I} 88$ os as 'a pleasant looking girl of about fourteen years, in a clean and new blanket which she had bought herself from beadwork she had made when watching the cattle, in anticipation of the time when she could find a chance to go to the mission station and learn'. The sale of her beadwork had been lucrative enough that she could buy new clothes at the station, and once there she became 'fixed in her purpose to become a Christian'. Family members came to fetch her but she refused to return;

7 I N. Etherington, 'Outward and visible signs of conversion in nineteenth-century Kwazulu-Natal', Journal of Religion in Africa, 32:4 (2002), 435-6. See also J. Comaroff and J. Comaroff, Of Revelation and Revolution, Volume II: The Dialectics of Modernity on a South African Frontier (Chicago, I997), 2 I 8-73.

72 KCM 52095, Inanda Seminary Papers Box ra, Letter dated Amanzimtoti, I7 May I893, signed Susan H. G. Ransom. 
eventually they left her completely alone. Later, she tried to visit them but found herself shunned by her family members; her father

would have nothing to do with her. The women of the kraal would not come near her, and they would not let any of the girls of the kraal speak to her nor did they offer her any food. She felt that she was an outcast.

Up to this point, this would seem to be a conventional story of conversion having split a girl off from her family, but in this case the girl was not content to be permanently estranged. Over the course of the next couple of years, as she continued to live on the mission station:

Again and again did she try to go to them and read to them and teach them; and gradually she has won her way back to their favor, till now they welcome her, and like to have her visit them. She would like to come out from native law [effectively be declared independent of her male legal guardian], but dares not ask her Father who is very old, and who has given orders to let her alone, hoping that when she marries, they will still get cattle for her. ${ }^{73}$

While superficially this narrative fits into a mission narrative stereotype - the virtuous Christian girl versus a heathen father who was solely motivated by the prospect of bridewealth cattle - it also tells a remarkable story of a Christian girl determined to maintain her relationship with her non-Christian family. Although the missionary writing the narrative glossed the father's desire to 'get cattle for her' as personal greed, it might have in fact reflected his desire for his daughter to be safely involved in a socially recognized and accepted marriage - a marriage that truly satisfied custom. The widely held belief among whites that women were little better than chattel in their own society created a 'rescue' frame of mind among missionaries that ignored evidence of the elasticity of African beliefs and family life.

Another case concerned a young woman about 16 years old who had been inspired by an African preacher to become a Christian: at a meeting between her family and the preacher, who was a local chief, she 'declared before all that she trusted she had given her heart to the Lord Jesus, and hoped from that day to follow Christianity.' Her mother 'at once got into a frenzy and pitched into Chief Dunge telling him that it was his preaching that had brought this calamity on her. She said she would not allow her child to become a Christian', and when her daughter later donned Western-style clothes, her mother 'tore them all off'. Although 'the Father was more reasonable and ... [tried] to prevent the mother from violently punishing the girl[,] she also assaulted her daughter ... She would strike the girl, and throw sticks of firewood at her, cursing her because she wished to be a Christian.' ${ }^{74}$

The daughter eventually appeared at the mission station on her own. According to the missionary, 'I asked who she was and was told she is the girl who had [been] insulted and abused by her mother because the girl wishes to kolwa [convert].' The girl continued, 'I want to enter the Girls' School.' When her mother appeared and demanded that her

73 KCM 52096, Inanda Seminary Papers Box Ia, unsigned narrative that is part of a series of narratives dated I 893 .

74 KCM 52090, Inanda Seminary Papers, Box Ia, letter, undated but probably I890, from H. M. Bridgman. 
daughter remove her clothes and return home, the daughter responded: 'No, I have come here to reside and to be in peace'. At that point the mother left the station and subsequently her husband's homestead, and returned to her own people apparently in disgust at the girl's decision. Her absence prompted the father to come to the mission station and plead with his daughter to return home, promising that 'at the end of the harvest, you can come back into the school, with approval'. The girl agreed, although whether the girl did come back to the mission after the harvest is not recorded. According to the missionary's conclusion to the story, "Now I hear the mother has come back to the husband [who] says "If you make any more trouble ... with this girl, she will go to the [mission] station and not come back." The girl is now making herself another dress. ${ }^{75}$

The cases of daughters converting to Christianity and attending school in defiance of their parents' wishes reveal the extent to which some women were able to claim spiritual autonomy as Christians, similar to the autonomy claimed by women who heeded the call of the ancestors to divine. While missionaries played a role in cultivating women's claims to Christian spirituality, it was the girls and young women themselves who insisted that they provide a refuge and often an education. ${ }^{76}$ The conversion experiences of these girls and young women usually appear in the letters as individual spiritual choices rather than as a search for individual or social healing. But, as Chidester notes, conversion might have been one way to quiet the demands of the ancestors, demands which white rule made difficult to fulfill. If some of these girls had heard the call to divine and were resisting it, perhaps because of prior exposure to Christian teachings, conversion could provide a spiritual alternative as well as an alternative community on the mission station. While families often denied that the girls had the right to make an independent choice to convert (and there certainly were cases in which girls were not successful in remaining at the mission stations), in the end families sometimes had to accede to their daughters' decisions. Conversion of an individual daughter did not always result in the daughter's expulsion from her family, and the beliefs of some families proved elastic enough to contain their Christian daughters within their families. Although these converts represented the disruption to family life caused by colonial intrusion, they also had the potential to heal the broader social disruptions faced by families within the colonial context.

\section{CONCLUSION}

These cases of women Christian converts and of diviners who combined elements of Christianity and their traditional practices raise some provocative questions for historians of gender in the South African context, as well as for the history of religious conversion and divination. The notion that women had access to spiritual authority even as they lost social and economic power during colonization and industrialization accords with recent

75 Ibid.

76 Shula Marks's study of the schoolgirl Lily Moya and her defiance of her uncle's wishes in search of education is a more detailed case study of this phenomenon. See S. Marks, Not Either an Experimental Doll: The Separate Worlds of Three South African Women (Bloomington, IN, I987), 9-30 and S. Marks, 'Changing history, changing histories: separations and connections in the lives of South African women', Journal of African Cultural Studies, I3:I (2000), 94-106. 
scholarship on women in Southern Africa: the society remained patriarchal, but women were often able to create some autonomy and status for themselves as individuals.

Beyond their individual claims to status, however, these women also became cultural mediators who borrowed, adopted, and combined spiritual beliefs to provide more complete answers to problems faced by rural African families in South Africa. They often were not directly challenging the white-controlled state or the power of African patriarchs but instead were addressing the spiritual needs of clients and family. Thus, the diviner Annie Cele, who practiced divination informed by the Christian God to determine the causes of a young girl's death, and the young convert Nomame, who faced extreme disapproval by family members as she sought education at the mission, were both responding in spiritual ways to new problems imposed on African family life by the advent of white rule. Some families were pulled apart as accidents and illnesses begged for explanations and diviners named family members as witches. The supernatural explanations offered by diviners posed one type of resolution. Some daughters, though, sought an alternative type of spiritual resolution by converting to Christianity while still retaining family ties. The access to spiritual knowledge that divination and conversion provided allowed women to claim spiritual authority and use it to try to control some of the violence and disruption of the changing social context in the nineteenth and twentieth centuries. 